\title{
The Politics of Economics
}

Dr. Alonzo Redmon, Economics, North Carolina A\&T State University

\begin{abstract}
The purpose of this article is to examine the relationship between presidential politics and economic policy. Does it make a difference, from an economic perspective, as to what political party occupies the oval office? With evidence of voter discontentment (rise of Ross Perot, low voter turnout), this would seem to be a most relevant question. Using economic variables, it is found that presidents can and do influence economic events. In fact, the president's party affiliation can be used as an indicator as to what economic policies will be implemented.
\end{abstract}

\section{Introduction}

It is no secret that more than a few Americans are disillusioned with the political process in this country. This has been partly evidenced by the increased interest in Ross Perot and what might be called a third party movement. The supporters of Ross Perot as well as others have felt left out of the political process or disappointed that politicians do not appear to respond to their concerns. These Americans see the political arena as something apart from their own existence.

There is a general feeling that politicians and their political parties are ruled by special interest groups and the concerns of the "average" voter do not count. The socalled "average" voter perceives that the actions and interests of politicians are directed toward pleasing the narrow interests of those who contributed large sums of money toward their campaigns. Such issues as unemployment and the standard of living for those not in the higher income brackets are marginal concerns.

This frustration with the political process has manifested itself in different ways. First, as shown in Table I, voters are simply not turning out to vote in presidential elections. In not one presidential election since World War II did the winner receive forty percent of those eligible to vote. The highest rate of participation was in 1964 , when $37.8 \%$ of the voting age population voted for the winner. In fact, the percentage of the votingage population that did not vote for the winner was higher than the percentage of the popular vote received by the winner in the presidential election. The implication of this is that a higher turnout could possibly have changed the results of the elections.
Another area where the frustration with the political process has manifested itself is in the current movement to set term limits for political office. Proponents of this view argue that our political system (i.e., campaign election laws) favors incumbents and it is very difficult to get those incumbents out of office. Further, the incumbents use their offices, many times to further their own personal agendas.

Given the feeling of the electorate, it would seem appropriate to consider whether, in fact, it does make a difference as to what political party wins the presidency? Do the policies of Republican administrations and Democratic administrations differ to a significant degree? For the vast majority of Americans, does it matter who occupies the Oval office?

\section{Economic Perspective}

This analysis will consider the distinguishing characteristics in each political administration from an economic perspective. Obviously there are other variables that are indicative of the performance of an administration such as international relations and the degree of openness with the electorate. However, economic variables are desirable for three reasons. First, economic performance of an administration has always been a topic of intense discussion when attempts are made to ascertain what can be called the success or failure of an administration. Second, economic performance is indicative of the standard of living and wealth level of the nation and as a result holds interest for people in all levels of society. Finally, economic data is relatively easy to obtain. 


\begin{tabular}{|c|c|c|c|}
\hline \multicolumn{4}{|c|}{$\begin{array}{c}\text { Table I } \\
\text { Voter Turnout In Presidential Elections }\end{array}$} \\
\hline Election & Election & Percentage of Vote & $\%$ of Voting Age \\
\hline$\underline{\text { Year }}$ & $\underline{\text { Winner }}$ & $\underline{\text { Received by Winner }}$ & Pop. Voting for Winner \\
\hline 1948 & Truman & 49.6 & 25.3 \\
\hline 1952 & Eisenhower & 55.1 & 34.0 \\
\hline 1956 & Eisenhower & 57.4 & 34.1 \\
\hline 1960 & Kennedy & 49.7 & 31.2 \\
\hline 1964 & Johnson & 61.1 & 37.8 \\
\hline 1968 & Nixon & 43.4 & 26.4 \\
\hline 1972 & Nixon & 60.7 & 33.5 \\
\hline 1976 & Carter & 50.1 & 26.8 \\
\hline 1980 & Reagan & 50.7 & 26.7 \\
\hline 1984 & Reagan & 58.8 & 31.2 \\
\hline 1988 & Bush & 53.4 & 26.8 \\
\hline 1992 & Clinton & 43.2 & 23.8 \\
\hline urce: & ional $Q u$ & Weekly, January 21 & the Census Bureau. \\
\hline
\end{tabular}

\section{Relevance of Issue}

Whether or not the major political parties in this country have different points of view or different ideologies is relevant for many reasons. First, if the parties do have different ideologies, then it does make a difference which party is in power. One hypothesis that will be considered in this paper and one that has been subject to spirited debate over time is that the Democratic party is more concerned about output than inflation. Democrats work to keep unemployment down and are willing to accept higher inflation as a trade-off. Republicans, on the other hand, are less willing to tolerate higher rates of inflation. Presumably, this is to accommodate their more upscale supporters. As a tradeoff, the Republicans are willing to tolerate more unemployment and slower growth to keep inflation down.

A second reason that it is relevant to study whether differences do exist between political parties is that if differences do in fact exist, they can impact the financial marketplace in different ways. By knowing what policies the political party in power are likely to pursue, business firms, as well as other institutions, can make better operational plans.

\section{Limitation of Results}

Before directly considering the issue of whether the presidential administrations in this country have different ideologies and whether those ideologies have been transformed into economic realities, some limitations should be discussed.

There are limitations as to what the president can do. Do to these constraints, the president can't institute purely ideological policies. First, there is the federal bureaucracy that must be dealt with. The bureaucracy consists of thousands of employees many of whom are in nonpolitical and very secure positions. Because of this, the initiatives that the president offers are not always followed exactly, if at all. This inability to get orders followed to the letter puts a restraint on what can be accomplished.

A second limitation on presidential influence is the state of the economy. If the economy is in a weakened state, a policy to pay off government debt by increasing income taxes could be dangerous for the economy. On the other hand, if there was a high rate of inflation, policies that are expansionist could bring about an even worse inflationary scenario. Therefore, in pursuing a particular ideology, 
care must be taken in recognizing what current economic conditions prevail and how possible policy actions will affect those conditions.

A third constraint on presidential power is the budgetary constraint. The federal budget, although initiated by the president, must go through Congress. Invariably, compromises and changes are made. Once again, the power to push through a purely ideological document is limited, if not nonexistent.

Probably the most significant limitation on presidential behavior is that every four years the electorate decides whether or not the administration stays or goes. Politicians want to stay in power. No ideology can be pursued if the politician is not in office. Therefore regardless of what ideal course of action the administration wishes to pursue, it must be tempered by re-election considerations. This may mean abandoning the "party line" and instituting policies purely to increase re-election chances - to win over

\section{Table II}

Percentage Change In Real GNP per capita (1987 dollars)

Democratic Administrations

\begin{tabular}{lrrrr} 
President/Year & $\underline{1}$ & $\underline{2}$ & $\underline{3}$ & $\underline{4}$ \\
Truman & -1.36 & 6.88 & 8.10 & 2.50 \\
Kennedy/Johnson & 1.08 & 3.61 & 2.64 & 4.22 \\
Johnson & 4.23 & 4.58 & 1.52 & 3.15 \\
Carter & 3.55 & 3.67 & 1.71 & -1.71 \\
Clinton & 1.98 & & & \\
Average & 1.90 & 4.69 & 3.49 & 2.04 \\
Average first/second halves & \multicolumn{2}{c}{3.30} & \multicolumn{2}{c}{2.77}
\end{tabular}

Republican Administrations

\begin{tabular}{lrrrr} 
President/Year & $\underline{1}$ & $\underline{2}$ & \multicolumn{3}{l}{} & $\underline{4}$ \\
Eisenhower I & 1.97 & -2.37 & 3.84 & .26 \\
Eisenhower II & .14 & -2.24 & 3.67 & .15 \\
Nixon I & 1.66 & -1.12 & 1.63 & 4.01 \\
Nixon/Ford & 4.43 & -1.40 & -2.02 & 4.06 \\
Reagan I & .60 & -3.21 & 2.84 & 5.03 \\
Reagan II & 1.97 & 1.83 & 2.05 & 3.06 \\
Bush & 1.72 & .28 & -1.77 & 1.00 \\
Average & 1.78 & 1.18 & 1.46 & 2.51 \\
Average first/second halves & \multicolumn{2}{c}{1.48} & \multicolumn{2}{c}{1.99}
\end{tabular}

Source: Calculations based on data obtained from the Bureau of Economic Analysis. voters who were not considered part of the original constituency. As the election approaches, popularity can carry a heavier weight than ideology.

\section{Analysis}

With the aforementioned caveats in mind, the central issue of an administration's influence on economic variables will now be considered. Does it matter what political party controls the White House? Can an administration influence the economy and does an administration influence the economy?

To address these issues, three economic variables have been chosen for analysis - the percentage change in real GNP per capita, the unemployment rate, and the change in the rate of inflation, as measured by the implicit price deflator. These variables have been chosen because they often enter into discussions about the performance of the economy and the performance of the administration. Also other studies in this area, including Fair (1978), Bruno and Schneider (1978), and Young, Marcus, Koot, and Mevorach (1990) have found that these variables or how an administration addresses these variables influences the electorates' political preferences.

Table II shows the percent change in real GNP per capita under Republican and Democratic administrations starting with the Truman administration elected in 1948. The percent change in real GNP is given on an annual basis for each administration. In comparing the Republican and Democratic administrations, the results are striking. In every Democratic administration, where data is available, real GNP per capita has increased from the first to second years. This could be an indication, as mentioned earlier, of the emphasis Democrats place on output and growth. The Republican administrations, on the other hand, show an entirely different picture. In every Republican administration, real GNP per capita decreases from the first to second years. This could be indicative of the fact that Republicans place more of an emphasis on holding down inflation than on output. 


\section{Table III Unemployment Rates - All Civilian Workers}

Democratic Administrations

\begin{tabular}{lllll} 
President/Year & $\underline{1}$ & $\underline{2}$ & $\underline{3}$ & $\underline{4}$ \\
Truman & 5.9 & 5.3 & 3.3 & 3.0 \\
Kennedy/Johnson & 6.7 & 5.5 & 5.7 & 5.2 \\
Johnson & 4.5 & 3.8 & 3.8 & 3.6 \\
Carter & 7.1 & 6.1 & 5.8 & 7.1 \\
Clinton & 6.8 & & \multicolumn{2}{c}{4.7} \\
Average & 6.2 & 5.2 & 4.7 & 4.7 \\
Average first/second halves & \multicolumn{2}{c}{5.7} & \multicolumn{2}{c}{4.7}
\end{tabular}

Republican Administrations

\begin{tabular}{lllll} 
President/Year & $\frac{1}{2}$ & $\underline{2}$ & $\underline{3}$ & $\underline{4}$ \\
Eisenhower I & 2.9 & 5.5 & 4.4 & 4.2 \\
Eisenhower II & 4.3 & 6.8 & 5.5 & 5.5 \\
Nixon I & 3.5 & 4.9 & 5.9 & 5.6 \\
Nixon/Ford & 4.9 & 5.6 & 8.5 & 7.7 \\
Reagan I & 7.6 & 9.7 & 9.6 & 7.5 \\
Reagan II & 7.2 & 7.0 & 6.2 & 5.5 \\
Bush & 5.3 & 5.5 & 6.7 & 7.4 \\
Average & 5.1 & 6.4 & 6.7 & 6.2 \\
Average first/second halves & \multicolumn{2}{c}{5.9} & \multicolumn{2}{c}{6.5}
\end{tabular}

Source: Economic Report of the President, January 1993 and Survey of Current Business, March 1994.

chances or their party's chances of reelection. This is regardless of the ideology of the administration in power.

The second economic variable to be considered is the unemployment rate. Once again, there are some significant differences between the Democratic and Republican administrations. In every Democratic administration the unemployment rate goes down from the first to the second years. In fact, with some exceptions, the overall trend of unemployment under Democratic administrations is downward. The annual average unemployment rate in each Republican administration, with the exception of the first year, is higher than the corresponding Democratic administrations.

For the Republicans, with the exception of the second term of the Reagan administration, the unemployment rate rises from years one to two. This could further support the notion that Republican administrations are more willing than Democrats to accept higher unemployment rates to keep inflation down. Although the unemployment rate goes down in every Republican administration with the exception of the second Eisenhower term, the average of the second half unemployment is significantly higher for Republican administrations than for Democratic administrations.

The third economic variable to be analyzed is inflation as measured by the

Further, the average in the first two years of the Democratic administrations, 3.30 is significantly higher than the first two years of the Republican administrations. The second halves of the respective administrations show a similar picture. The average of the last two years for the Democrats is still higher than for the Republicans, although the spread between the two is not as great.

However, there is a further point worth noting. In half of the Democratic administrations, Kennedy/Johnson and Johnson, and the majority of the Republican administrations, Nixon I, Nixon/Ford, Reagan I, and Reagan II, the real GNP per capita increased from year 3 to year 4 of the administrations. Given that the fourth year is the election year, this result is most logical and expected. The incumbent administration increases output to be more popular with the electorate and therefore to increase their percentage change in the implicit price deflator. This information is given in Table III. As expected, all Democratic administrations show an increase of inflation from years one to two in their administrations. This is, once again, consistent with the premise that Democratic administrations are willing to tolerate higher inflation rates in return for lower unemployment and higher output. The Republicans, in the first half of their administration, show a decrease or no change in the inflation rates for all but two administration. This is consistent with the premise that Republican administrations want to keep inflation rates low to appeal to the upper income groups who put them in office.

Although in the second half of the administrations there are no obvious distinguishable characteristics between the two parties, in half of the Democratic administrations and 


\begin{tabular}{|c|c|c|c|c|}
\hline \multicolumn{5}{|c|}{$\begin{array}{c}\text { Table IV } \\
\text { Percentage Change In The Implicit Deflator (1987 dollars) }\end{array}$} \\
\hline \multicolumn{5}{|l|}{ Democratic Administrations } \\
\hline President/Year & $\underline{1}$ & $\underline{2}$ & $\underline{3}$ & $\underline{4}$ \\
\hline Truman & -.50 & 1.51 & 5.45 & .94 \\
\hline Kennedy/Johnson & .77 & 2.28 & 1.12 & 1.81 \\
\hline Johnson & 2.53 & 3.52 & 3.06 & 4.95 \\
\hline Carter & 6.88 & 7.87 & 8.79 & 9.30 \\
\hline Clinton & 2.15 & & & \\
\hline Average & 2.37 & 3.80 & 4.61 & 4.25 \\
\hline Average first/second halves & 3. & & & \\
\hline \multicolumn{5}{|l|}{ Republican Administrations } \\
\hline$\underline{\text { President/Year }}$ & $\underline{1}$ & $\underline{2}$ & $\underline{3}$ & $\underline{4}$ \\
\hline Eisenhower I & 2.33 & .91 & 3.15 & 3.06 \\
\hline Eisenhower II & 3.39 & 2.05 & 2.81 & 1.95 \\
\hline Nixon I & 5.03 & 5.39 & 5.40 & 4.85 \\
\hline Nixon/Ford & 6.17 & 8.72 & 9.58 & 6.30 \\
\hline Reagan I & 10.88 & 6.21 & 4.06 & 4.47 \\
\hline Reagan II & 3.62 & 2.65 & 3.20 & 3.90 \\
\hline Bush & 4.43 & 4.33 & 3.89 & 2.81 \\
\hline Average & 5.12 & 4.32 & 4.58 & 3.91 \\
\hline Average first/second halves & \multicolumn{2}{|c|}{4.72} & \multicolumn{2}{|c|}{4.25} \\
\hline $\begin{array}{l}\text { Source: Calculations based } \\
\text { of the Bureau of Economic }\end{array}$ & $\begin{array}{l}\text { a data } \\
\text { alysis. }\end{array}$ & tained & om the & Bureau \\
\hline
\end{tabular}

\section{Conclusion}

The paper has examined the political administrations from 1949 to the present to see if there are significant differences, in terms of economic impact, between Republican and Democratic administrations. This issue continues to be a topic of "hot" discussion among the general electorate, as well as on academic, business, and political levels. If there are significant differences between the economic policies and their effect on the economy, it should be an encouragement to all that voting is important. Also, as mentioned in the analysis, businesses can make better operational plans if they know what direction the economy is headed.

The results of this study give a clear indication that political administrations do affect the economy in different fashions. Democratic administrations do seem to be willing to accept higher levels of inflation than Republican administrations. This is due at least partly to the fact that the Democrats tend to set a higher priority on high output and low inflation. Another interesting result of this analysis is that as election day grows nearer, regardless of ideology, either party is willing to forsake ideology and make policy moves to woe voters. This is evidenced by the Democrats, in general, lowering inflation and the Republicans lowering unemployment in the later part of their administrations.

\section{Suggestions For Further Research}

Analyzing the impact of presidential policies more than half of the Republican administrations the inflation rate falls in the second half of the administrations. This could be a move by each political party, regardless of ideology, to get popularity points from the electorate.

The results of this analysis are consistent with the results of other studies done in this area. Young, Marcus, Koot, and Mevorach (1990) found that, as in this study, that Democratic administrations, in general, do better in the area of unemployment administrations, in general, do a better job in keeping inflation down than Democratic administrations. than Republican administrations. Juster (1988) found, that in general, Democratic administrations do better when in comes to increasing output than Republican administrations.

on economic variables is certainly an important exercise in a democracy, since the electorate is concerned about economic conditions, and at least to some degree, will vote accordingly. Many other avenues of research are suggested by this present study.

First of all, unemployment, which is one of the variables used in this study could be desegregated. Unemployment could be analyzed by occupation, by age, by sex, by race and/or by region of the country. It would certainly appear to be relevant, as well as interesting, to see if the above categories of unemployment are affected differently by who occupies the White House.

Inflation, another variable used in this study, could be broken down by specific products or groups of products. 
For example, are consumer goods and industrial goods affected differently by presidential policies.

Real GNP per capita, the third variable used in this study, could be calculated for various industries or sectors of the economy. Some areas of the economy are more productive than others. Some areas of the economy receive assistance from the government while others do not. It would be interesting to see how these different areas are affected by presidential policies.

Besides breaking down the variables used in the study, additional variables such as stock market performance and personal income could be included. This is an area obviously ripe for further research.

\section{References}

1. Alesina, Alberto and Sachs, Jeffrey. "Political Parties and the Business Cycle in the United States, 19481984," Journal of Money, Credit, and Banking, Vol. 20 , no. 1 , February 1988 , pp. 63-82.

2. Alfred, Marcus A., Koot, Ronald S.,Mevorach, Baruch, and Young, Peg. "Improved Business Planning through an Awareness of Political Cycles," Journal of Forecasting, Vol. 9, 1990, pp. 37-51.

3. Cook, Rhodes. "Turnout Hits 64-Year Low in Presidential Race," Congressional Quarterly Weekly, January 21, 1989, p. 137.

4. Economic Report of the President, February 1990.

5. Economic Report of the President, January 1993.

6. Fair, Ray C. "The Effect of Economic Events On Votes For President," The Review of Economics and Statistics, Vol. 60, number 2, May 1978, pp. 159-172,

7. Frey, Bruno S. and Schneider, Friedrich. "An Empirical Study of Politico-Economics Interaction In The United States," The Review of Economics and Statistics, number 2, May 1978, pp. 174-183.

8. Hibbs, Douglas A., Jr. The American Political Economy, Harvard Press, Cambridge, Massachusetts, and London, England, 1987.

9. Juster, F. Thomas. "Economic Policy Issues and the Election Does It Matter Who Wins?" Economic Outlook USA, Autumn 1988, pp. 14-20.

10. Survey of Current Business, March 1994.

11. United States Department of Commerce, Economics and Statistics Administration, Bureau of Economic Analysis, Washington, D.C. 